\title{
Effects of an Antioxidant on the Shear Bond Strengths of Orthodontic Brackets \\ After Conventional and Laser-Assisted Extra-Coronal Bleaching
}

\author{
Efecto de un antioxidante sobre la fuerza de unión \\ de brackets de ortodoncia \\ posterior al blanqueamiento convencional y asistido por láser
}

Funda Fundaoĝlu Küçükekenci DDS1; Ahmet Serkan Küçükekenci DDS, PhD²; Süleyman Kutalmiş Büyük DDS, PhD³

1. Practitioner, Ordu Public Oral Health Hospital, Ordu, Turkey.

2. Ordu University, Faculty of Dentistry, Department of Prosthodontics, Ordu, Turkey.

3. Ordu University, Faculty of Dentistry, Department of Orthodontics, Ordu, Turkey.

Correspondence to: Ahmet Serkan Küçükekenci - serkankucukekenci@gmail.com

Received: 2-V-2018

Accepted: 26-VI-2018

Published Online First: 2-VII-2018

DOl: https://doi.org/10.15517/ijds.v0i0.33881

\section{ABSTRACT}

Purpose: The purpose of this study was to evaluate the effects of the application of antioxidant on the shear bond strengths (SBS) of orthodontic brackets bonded to human enamel after extra-coronal bleaching with hydrogen peroxide (HP). Materials and methods: Fifty freshly extracted premolars were randomly divided into three groups. One group (Group 1) was bleached with 40\% HP ( $n=20)$, another group (Group 2) was bleached with 40\% HP and activated with an Nd: YAG laser ( $n=20)$, and a control group (Group 3) received no treatment $(n=10)$. After the bleaching procedure, Groups 1 and 2 were further divided into two subgroups (Group 1a, Group 1b, Group 2a, and Group 2b). Specimens in Groups $1 \mathrm{a}$ and $2 \mathrm{a}(n=10)$ received no antioxidant application. A $10 \%$ sodium ascorbate solution was applied to specimens in Groups $1 \mathrm{~b}$ and $2 \mathrm{~b}(n=10)$. The brackets were then bonded with light-cure adhesive paste to the enamel surfaces of all experimental groups. Specimens were subjected to SBS tests for debonding. Results: The SBS of brackets bonded in Groups 1 and 2 were significantly lower than those of brackets bonded to the control group $(p<0.001)$; however, no statistically significant differences in SBS were noted in Groups 1 and 2 ( $p>0.001$ ). The antioxidant-treated SBS of brackets in Groups $1 \mathrm{~b}$ and $2 b$ were significantly higher than those of Groups $1 \mathrm{a}$ and $2 \mathrm{a}(\mathrm{p}<0.001)$. Conclusions: The application of $40 \% \mathrm{HP}$ had a negative effect on the bond strength. The use of antioxidant for 15 min resulted in the reversal of failed bond strength.

\section{KEYWORDS}

Bleaching; Hydrogen peroxide; Brackets; Nd:YAG laser; Sodium ascorbate; Shear bond strength. 


\section{RESUMEN}

El objetivo del presente estudio fue evaluar los efectos de la aplicación de un antioxidante sobre las fuerzas de unión (SBS) de brackets de ortodoncia posterior al blanqueamiento con peróxido de hidrógeno (HP). Metodología: Cincuenta premolares recién extraídos se dividieron aleatoriamente en tres grupos. El Grupo 1 se trató con 40\% de HP $(n=20)$, el grupo 2 con 40\% de HP y se activó con láser de Nd: YAG ( $n=20)$ y un grupo de control (Grupo 3) no recibió tratamiento $(n=10)$. Después del blanqueamiento, los Grupos 1 y 2 se dividieron en dos subgrupos (Grupo 1a, Grupo 1b, Grupo 2a y Grupo $2 b)$. Las muestras en los subgrupos 1a y 2a $(n=10)$ no recibieron ninguna aplicación del antioxidante. Se aplicó una solución de ascorbato de sodio al 10\% a las muestras en los Grupos 1b y 2b $(n=10)$. Luego, los brackets se adherieron a las superficies de esmalte de todos los grupos experimentales. Las muestras se sometieron a pruebas de SBS y los datos analizados estadisticamente. Resultados: La fuerza de unión de los grupos 1 y 2 fue significativamente más baja que el grupo de control ( $<<0.001)$; sin embargo, no se observaron diferencias estadísticamente significativas en SBS entre los grupos 1 y 2 ( $p>0.001$ ). Las muestras tratadas con antioxidantes de los grupos $1 b$ y $2 b$ fueron significativamente mayores que las de los grupos 1a y 2 a ( $p<0,001)$. Conclusion: La aplicación de 40\% HP tuvo un efecto negativo en la resistencia de unión de los brackets. El uso de antioxidante durante 15 minutos mejoró significativamente la SBS.

\section{PALABRAS CLAVE}

Blanqueamiento; Peróxido de hidrógeno; Brackets ortodoncia; Láser Nd: YAG; Ascorbato de sodio; Resistencia al cizallamiento.

\section{INTRODUCTION}

Tooth discoloration remains one of the most significant esthetic challenges in dentistry, which is affected by many complex etiologic factors, usually classified as intrinsic, extrinsic, or intrinsic to nature $(1,2)$. Numerous treatment options exist for discolored teeth, such as bleaching, laminate, and placement of esthetic prosthetic restorations (3). Bleaching is a safe and conservative treatment method for intrinsic staining of the tooth surface (4). In-office bleaching is one of the various approaches identified as treatment options for vital teeth.

In bleaching processes, hydrogen peroxide $(\mathrm{HP})$, sodium perborate (SP), and carbamide peroxide (CP) have been used for many years in dentistry. To accelerate the bleaching procedure, heat and light sources can be used in a method described as activated bleaching $(5,6)$. Many light sources have been used to accelerate the bleaching process (7). Light sources such as plasma arc lamps, halogen lights, light-emitting diode (LED) systems, and laser systems are used to facilitate the bleaching procedure by accelerating the delivery of hydroxyl $(\mathrm{OH}-)$ radicals that are used to bleach the teeth $(5,8,9)$. Tooth bleaching has side-effects such as tooth or gum sensitivity; however, when a laser is used for bleaching, tooth sensitivity is decreased (10). $\mathrm{CP}$ is a reliable, well-known bleaching agent (11).

Along with these advantages, bleaching agents also have some disadvantages (12). One of the most important complications in using bleaching agents is the reduction of enamel and composite resin bonding strength immediately after the bleaching procedure $(13,14)$. The bonding weakness may be intrinsic or superficial and is thought to originate from the fact that the residual whitening agent prevents resin polymerization (11). Various studies 
have shown that bonding affinity can be reversed by the application of solutions with different concentrations of antioxidant agents. Antioxidants are substances that enter the reaction with free radicals and neutralize it (15). Other studies have reported that the impact on bond strength could be reversed by the application of solutions with different concentrations of antioxidant agents, such as sodium ascorbate $(16,17)$. In addition to sodium ascorbate, there are many antioxidant agents, such as ascorbic acid, butyl hydroxy anisole, catalase, glutathione ethanol peroxide, sodium bicarbonate, alpha-tocopherol, acetone, and green tea extract catechins (18).

The authors report that the mean shear bond strength (SBS) of orthodontic brackets with bleached enamel is significantly lower than that with unbleached enamel corresponding to the bleaching type (19-21). However, other studies have presented no significant differences in mean SBS between bleached and unbleached teeth $(22,23)$. Therefore, influence on the bonding of brackets after bleaching remains controversial.

The aim of this study was to identify the effect of $10 \%$ sodium ascorbate on the immediate SBS of orthodontic brackets bonded to laser-assisted ( $\mathrm{Nd}$ YAG) bleached and conventional bleached enamel. The following study hypotheses were tested: (i) the use of antioxidant solutions would have no impact on the SBS of an orthodontic bracket bonded to a bleached enamel surface compared with that to an unbleached control surface and (ii) there would be no difference in the SBS to laser-assisted bleached and conventional bleached enamel.

\section{MATERIALS AND METHODS}

\section{SPECIMEN PREPARATION}

Fifty human first premolars freshly extracted for orthodontic purposes were selected. The inclusion criteria for tooth choice were as follows: unspoiled enamel, no previous treatment with acid or any peroxide solution, no restorations, no caries, and no cracks. First, they were disinfected by immersion in $0.5 \%$ chloramine-T solution (Merck, Germany) for a day. The crowns of the teeth were separated from their roots by being cut with a diamond disk $2 \mathrm{~mm}$ below the cementoenamel junction and embedded in autopolymerizing acrylic resin blocks (Panacryl; Arma Dental, Istanbul, Turkey) with their buccal surfaces exposed to ensure that the applied force during the shear test of the labial surfaces would be parallel. The specimen surfaces were then flattened by means of \#600grit silicon carbide paper under water. Specimens were ultrasonically cleaned (Branson 8510; Branson Ultrasonics, Danbury, USA) for $10 \mathrm{~min}$. The schematic representation of the experimental groups treated with different combinations of bleaching/ antioxidant procedures is presented in Table 1.

An extra-coronal bleaching agent containing 40\% HP (Opalescence Boost; Ultradent Products, South Jordan, Utah, USA) was used in the present study. Clinicians used two protocols to simulate the bleaching methods, in accordance with the manufacturer's direction.

In the group designated for conventional bleaching, three applications (20 min each) of the bleaching agent were used on each enamel specimen. After each application, the bleaching agent was removed with a 1 -min water rinse. This procedure was repeated three times during the session, with intervals of 5 min between each application.

In the group designated for laser-assisted bleaching, the bleaching agent was applied to the enamel surface of each specimen, then activated by the Nd:YAG laser (Deka smart file; DEKA, Italy) (1064 nm; output power, $2.0 \mathrm{~W}$; pulse repetition rate, $40 \mathrm{~Hz}$; pulse duration, $100 \mu \mathrm{s}$; and energy density, $0.50 \mathrm{~J} / \mathrm{cm} 2)$ for $30 \mathrm{~min}$. 
The bleaching agent was kept on the enamel for 10 min and then removed with a 1-min water rinse. This process was repeated three additional times with 1-min intervals between each application.

After the bleaching process, a 10\% sodium ascorbate solution (Alfasol; Kimbiotek, Istanbul, Turkey) was prepared and immediately applied to subroups 2 and 4 . This solution was spread on the enamel with its own microbrush. After a $15 \mathrm{~min}$ wait for both applications, the solution was washed off with water spray and the samples were dried.

\section{BONDING PROCEDURE AND BOND STRENGTH TEST}

The enamel specimens were acid etched for 30 s with a 35\% phosphoric acid gel (Scotchbond Etchant; 3M ESPE, St. Paul, MN, USA) and then water rinsed for $1 \mathrm{~min}$ and gently air-dried. After the etching process, Transbond XT Adhesive Primer was applied to the etched surfaces (3M Unitek) according to the manufacturer's directions and light cured for $20 \mathrm{~s}$ with a LED light-curing unit (Valo Cordless; Ultradent, South Jordan, UT).

Following surface conditioning and the application of primer, light-curing bonding resin (Transbond XT; 3M Unitek) was applied to the under surfaces of brackets. Fifty premolar selfligating metallic brackets (Empower; American Orthodontics, Sheboygan, WI) were used in this research. The brackets were then fitted onto the enamel surface, and a slight pressure was applied to the upper surface of the bracket with a hand tool. Excess bonding resin was removed with microbrushes. The bonding resin was photopolymerized for a total of $20 \mathrm{~s}$ from two sides (mesial and distal) using a LED light-curing unit. The bonded samples were kept in deionized water at $37^{\circ} \mathrm{C}$ for $24 \mathrm{~h}$.

SBS testing was performed in a Universal Testing Machine (Instron; Lloyd Instruments, Fareham, UK) at a crosshead speed of $0.5 \mathrm{~mm} /$ min with a force parallel to the enamel/bracket interface and use of a knife-edge blade. The maximum load at debonding was calculated in Newton and converted into Megapascal.

After debonding, adhesive remnant index (ARI) scores were calculated under a stereomicroscope (Olympus SZX7; Hamburg, Germany) at 10x magnification. These scores ranged from 5 to 1 ( $5=$ no composite remained on the enamel; $4=$ less than $10 \%$ of composite remained on the tooth surface; $3=$ more than $10 \%$ but less than $90 \%$ of the composite remained on the tooth; $2=$ more than $90 \%$ of the composite remained; and $1=$ all of the composite, with an impression of the bracket base remained on the tooth) (24).

\section{STATISTICAL ANALYSIS}

According to the Shapiro-Wilk tests and the Kolmogorov-Smirnov test of normality, the groups were normally distributed ( $p>0.001)$. The SBS (MPa) data were analyzed by one-way analysis of variance (ANOVA). Finally, the mean SBS values were compared using Tukey's multiple comparison tests $(p<0.001)$.

The frequency distribution of the ARI scores among the groups was evaluated by descriptive statistics. Significance for all statistical tests was set at $p<0.05$. All computational work was performed with statistical software (SPSS version 20, SPSS Inc, USA).

\section{RESULTS}

SBS data in $\mathrm{MPa}$ (mean and SD) for the groups are presented in Table 2. One-way ANOVA showed statistically significant differences in bond strength values among the groups $(p<0.001)$.

A Tukey test showed that the SBS of brackets in groups bonded after being bleached with 40\% HP and 40\% HP+Nd:YAG laser were significantly lower than that of the control $(p<0.001)$; however, there 
was no statistically significant difference observed between the 40\% HP and 40\% HP+Nd:YAG laser groups ( $p>0.001$ ), indicating that laser assistance was not significantly effective on the SBS of brackets bonded to bleached enamel.

For the bleaching groups, when the antioxidant-treated groups were compared with the control group, there was a statistically significant difference in SBS $(p<0.001)$, indicating that antioxidant treatment was significantly effective in increasing the SBS of brackets bonded to bleached enamel. For the two bleaching groups, when the antioxidant-treated brackets were compared, no statistically significant difference was observed $(p>0.001)$.

The ARI scores are presented in Table 3.

Table 1. Experimental groups.

\begin{tabular}{|c|c|c|c|c|}
\hline \multicolumn{2}{|c|}{ Group 1} & \multicolumn{2}{|c|}{ Group 2} & $\begin{array}{c}\text { Group } 3 \\
\text { (Control group) }\end{array}$ \\
\hline \multicolumn{2}{|c|}{$40 \%$ HP $(n=20)$} & \multicolumn{2}{|c|}{$\begin{array}{l}\text { 40\% HP and activated with Nd:YAG laser } \\
\qquad(n=20)\end{array}$} & No bleaching $(n=10)$ \\
\hline Group 1a & Group 1b & Group 2a & Group 2b & \\
\hline $\begin{array}{l}\text { No surface treatment } \\
\qquad(\mathrm{n}=10)\end{array}$ & $\begin{array}{l}10 \% \text { sodium ascorbate } \\
\text { solution applied }(n=10)\end{array}$ & No surface treatment & $\begin{array}{l}10 \% \text { sodium ascorbate } \\
\text { solution applied }(n=10)\end{array}$ & \\
\hline
\end{tabular}

Table 2. Mean and standard deviation (SD) of the shear bond strength (SBS) (Mpa) of the different groups and Tukey Analysis.

$\begin{array}{ccccccc}\text { Groups } & \text { N } & \text { Mean } & \text { SD } & \text { Minimum } & \text { Maximum } & \boldsymbol{P} \\ \text { Group 1a } & 10 & 10.16 & 1.77 & 7.90 & 13.67 & \mathrm{ab} \\ \text { Group 1b } & 10 & 13.78 & 3.06 & 9.04 & 18.52 & \mathrm{bc} \\ \text { Group 2a } & 10 & 9.83 & 1.76 & 7.12 & 13.08 & \mathrm{a} \\ \text { Group 2b } & 10 & 12.17 & 2.92 & 8.66 & 16.75 & \mathrm{abc} \\ \text { Control } & 10 & 15.01 & 4.20 & 10.32 & 22.45 & \mathrm{c}\end{array}$

Same letters are not significantly different according to Tukey test.

Table 3. Location of adhesive layer after bracket failure.

\begin{tabular}{ccccccc}
\hline Groups & \multicolumn{7}{c}{ ARI score } & $\mathbf{3}$ \\
\hline & N & $\mathbf{1}$ & $\mathbf{2}$ & $\mathbf{3}$ & $\mathbf{4}$ & $\mathbf{5}$ \\
\hline Group 1a & 10 & 0 & 2 & 2 & 5 & 1 \\
Group 1b & 10 & 3 & 2 & 1 & 3 & 1 \\
Group 2a & 10 & 0 & 0 & 0 & 1 & 9 \\
Group 2b & 10 & 1 & 4 & 0 & 3 & 2 \\
Control & 10 & 3 & 2 & 2 & 2 & 1 \\
Total & $\mathbf{5 0}$ & $\mathbf{7}$ & $\mathbf{1 0}$ & $\mathbf{5}$ & $\mathbf{1 4}$ & $\mathbf{1 4}$ \\
\hline
\end{tabular}




\section{DISCUSSION}

According to the results of this research, the first null hypothesis that the use of an antioxidant solution would have no effect on the bond strength of metal brackets to bleached enamel surfaces in comparison with that of the unbleached control group was rejected. However, the second null hypothesis that there would be no difference in the bond strength of laser-assisted bleached enamel compared with conventional bleached enamel was accepted.

Because orthodontic treatment is frequently performed in adults, there is a patient population not satisfied with simply having a well-aligned dentition and who frequently require whiter teeth. There are many products and techniques available for bleaching teeth; however, but many of them have adverse effects on the bond strength of brackets to enamel surfaces $(19,25,26)$. Some studies $(23,27,28)$ have shown that the enamel surface with HP applied as a bleaching agent yields less bond strength than the enamel surface without the bleaching agent.

In our study, all groups showed the 6- to 8-MPa connecting force required to withstand orthodontic strength (29). It was observed that the SBS of the bleaching groups were significantly lower than those of the control group. According to Cavalli et al. (30) when the composite is bonded to enamel immediately after the bleaching procedure, the SBS decreases, which supports the results of our study.

Turkun and Kaya (31) examined the action of several concentrations $(10 \%, 16 \%$, and $20 \%)$ of CP on SBS of resin composite to bleached enamel. They demonstrated that all three concentrations of $\mathrm{CP}$ reduced the SBS, but high concentrations led to greater decreases.

The reduction in bond strength following bleaching procedures may be explained by higher grades of free radical peroxides at the bond interface, which disrupt polymerization and decrease bonding strengths (32). Some researchers (33) have proposed that residual bleaching agents have a bad influence on the bonding process and they have suggested to abrade the enamel surface to decrease any bleaching agents remaining on the enamel.

The adverse effects of remnant bleaching agents on bond strength can be reversed by the use of an antioxidant, such as sodium ascorbate (34). Sodium ascorbate is the most potent antioxidant for the reduction of free radicals (35). Gökce et al. (36) studied enamel to which external bleaching was applied and demonstrated that a week's delay or the administration of bleaching materials were efficient processes for counteracting the effects of bleaching agents.

In our study, the application of sodium ascorbate immediately after bleaching increased the bond strength. Hansen et al. (37) reported that the use of $35 \%$ sodium ascorbate had no significant effect on increasing bond strength after 35\% HP application for intracoronal bleaching. In contrast, according to the present study, the immediate application of sodium ascorbate increased bond strength. We believe that the internal bleaching process affects tooth structure more than the external bleaching process. Laser-assisted bleaching procedures can accelerate oxygen release and HP separation, with concomitant benefit to SBS $1 \mathrm{~h}$ after the bleaching process (38). However, Akin et al. (39) reported lower SBS values in both the groups with Nd:YAG laser-assisted bleaching and bleaching without a laser.

The ARI scores were significantly different among the groups. ARI scores of 4 and 5 were recorded, indicating that failures frequently occurred at the enamel-adhesive interface. These results differ from those of previous studies (33, 39). The ARI scores also explain that the cohesive 
strength generated by hybridization and bonding is higher than the adhesive strength of the surfaces. However, the factors influencing the SBS of brackets in the clinical setting cannot be simulated in vitro.

Limitations of the current study were used one type of bleaching agent and antioxidant solution in laboratory situations to evaluate the effects of the application of antioxidant on the SBS of orthodontic brackets bonded to human enamel after bleaching with HP. Within the limitations of this in-vitro study, the results showed the use of sodium ascorbate to have important clinical relevance for the bond strength of enamel/brackets.

\section{CONCLUSIONS}

The application of $40 \%$ HP had a negative effect on the bond strength. Laser assistance had no significant effect on the SBS of orthodontic brackets bonded to extra-coronally bleached enamel surfaces. The use of antioxidant solutions for 15 min resulted in the reversal of failed bond strength. Further in-vivo studies are required for conclusions to be drawn regarding the efficacy of various bleaching agents and antioxidants impact on the bond strength.

\section{ACKNOWLEDGMENTS}

None of the authors has financial interest related to this study to disclosure.

\section{CONFLICT OF INTEREST}

The authors declare that they have no conflict of interest.

\section{REFERENCES}

1. SuliemanM.Anoverview oftoothdiscoloration: extrinsic, intrinsic and internalized stains. Dent Update 2005; 32: 463-464, 466-468, 471.

2. Hafez R., Ahmed D., Yousry M., El-Badrawy W., El-Mowafy O. Effect of In-Office Bleaching on Color and Surface Roughness of Composite Restoratives. Eur J Dent 2010; 4:118-127.

3. Heymann H. O. Additional conservative esthectic procedures. In: Roberson T. M., Haymann H. O., Swift E. J. Sturdevent's Art and Science of Operative Dentistry, 5th edn. Noida, Reed Elsevier India Private Limited, 2009; pp 625-641.

4. Wille T., Pesun I. J., Combe E. C., Lindquist G. C., Hodges J. S. A clinical pilot study of the time-dependent composition of tooth bleaching systems. J Oral Rehabil 2003; 30: 510-514.

5. Zhang C., Wang X., Kinoshita J., Zhao B., Toko T., Kimura Y., et al. Effects of KTP laser irradiation, diode laser, and LED on tooth bleaching: a comparative study. Photomed Laser Surg 2007; 25: 91-95.

6. Buchalla W., Attin T. External bleaching therapy with activation by heat, light or laser-a systematic review. Dent Mater 2007; 23: 586-596.

7. Luk K., Tam L., Hubert M. Effect of light energy on peroxide tooth bleaching. J Am Dent Assoc 2004; 135:194-201.

8. Sydney G. B., Barletta F. B., Sydney R. B. In vitro analysis of effects of heat used in dental bleaching on human dental enamel. Braz Dent J 2002; 13:166-169.

9. Sulieman M., Addy M., Rees J. S. Surface and intra-pulpal temperature rises during 
tooth bleaching: an in vitro study. Braz Dent J 2005; 199:37-40.

10. Pohjola R. M., Browning W. D., Hackman S. T., Myers M. L., Downey M. C. Sensitivity and tooth whitening agents. J Esthet Restor Dent 2002; 14:85-91.

11. Dabas D., Patil A. C., Uppin V. M. Evaluation of the effect of concentration and duration of application of sodium ascorbate hydrogel on the bond strength of composite resin to bleached enamel. J Conserv Dent 2011; 14 : 356-360.

12. Basting R. T., Rodrigues J. A., Serra M. C., Pimenta L. A. Shear bond strength of enamel treated with seven carbamide peroxide bleaching agents. J Esthet Restor Dent 2004; 16: 250-259.

13. Oskoee P. A., Navimipour E. J., Oskoee S. S., Moosavi N. Effect of $10 \%$ sodium ascorbate on bleached bovine enamel surface morphology and microhardness. Open Dent J 2010; 4: 207-210.

14. Titley K. C., Torneck C. D., Smith D. C., Chernecky R., Adibfar A. Scanning electron microscopy observations on the penetration and structure of resin tags in bleached and unbleached bovine enamel. J Endod 1991; 17: 72-75.

15. Kimyai S., Valizadeh H. Comparison of the effect of hydrogel and a solution of sodium ascorbate on dentin-composite bond strength after bleaching. J Contemp Dent Pract 2008; 9: 105-112.

16. Lai S. C., Mak Y. F., Cheung G. S., Mak Y. F., Carvalho R. M., Wei S. H., et al. Reversal of compromised bonding to oxidized etched dentin. J Dent Res 2001; 80: 1919-1924.

17. Yeung S. Y., Huang C. S., Chan C. P., Lin C. P., Lin H. N., Lee P. H. Antioxidant and prooxidant properties of chlorhexidine and its interaction with calcium hydroxide solutions. Int Endod J 2007; 40: 837-844.

18. Garcia E. J., Oldoni T. L., Alencar S. M., Reis A., Loguercio A. D., Grande R. H.
Antioxidant activity by DPPH assay of potential solutions to be applied on bleached teeth. Braz Dent J 2012; 23: 22-27.

19. Miles P. G., Pontier J. P., Bahiraei D., Close J. The effect of carbamide peroxide bleach on the tensile bond strength of ceramic brackets: an in vitro study. Am J Orthod Dentofacial Orthop 1994; 106: 371-375.

20. Cacciafesta V., Sfondrini M. F., Stifanelli P., Scribante A., Klersy C. The effect of bleaching on shear bond strength of brackets bonded with a resin-modified glass ionomer. Am J Orthod Dentofacial Orthop 2006; 130: 83-87.

21. Bulut H., Kaya A. D., Turkun M. Tensile bond strength of brackets after antioxidant treatment on bleached teeth. Eur J Orthod 2005; 27: 466-471.

22. Uysal T., Basciftci F. A., Usumez S., Sari Z., Buyukerkmen A. Can previously bleached teeth be bonded safely? Am J Orthod Dentofacial Orthop 2003; 123: 628-632.

23. Josey A. L., Meyers I. A., Romaniuk K., Symons AL. The effect of a vital bleaching technique on enamel surface morphology and the bonding of composite resin enamel. J Oral Rehabil 1996; 23: 244-250.

24. Bishara S. E., VonWald L., Olsen M. E., Laffoon J. F. Effect of time on the shear bond strength of glass ionomer and composite orthodontic adhesives. Am J Orthod Dentofacial Orthop 1999; 116: 616-620.

25. Bulut H., Turkun M., Demirbaş Kaya A. Effect of an antioxidizing agent on the shear bond strength of brackets bonded to bleached human enamel. Am J Orthod Dentofacial Orthop 2006; 129: 266-272.

26. Bishara SE, Sulieman A, Olson M. Effect of enamel bleaching on the bonding strength of orthodontic brackets. Am J Orthod Dentofacial Orthop 1993; 104: 444-447.

27. Stokes A. N., Hood J. A. A., Dhariwal D., Patel K. Effect of peroxide bleaches on resin-enamel bonds. Quintessence Int 1992; 23: 769-771. 
28. Garcia-Godoy F., Dodge W. W., Donohue M., O'Quinn J. A. Composite resin bond strength after enamel bleaching. Oper Dent 1993; 18:144-147.

29. Reynolds J. R. A review of direct orthodontic bonding. J Orthod 1975; 2: 171-178.

30. Cavalli V., Reis A. F., Giannini M., Ambrosano G. M. The effect of elapsed time following bleaching on enamel bond strength of resin composite. Oper Dent 2001; 26: 597-602.

31. Turkun M., Kaya A. D. Effect of $10 \%$ sodium ascorbate on the shear bond strength of composite resin to bleached bovine enamel. J Oral Rehabil 2004; 31:1184-1191.

32. McGuckin R. S., Thurmond B. A., Osovitz S. Enamel shear bond strengths after vital bleaching. Am J Dent 1992; 5: 216-222.

33. E. Öztaş, G. Bağdelen, H. Kılıçoğlu, Ulukapi H., Aydin I. The effect of enamel bleaching on the shear bond strengths of metal and ceramic brackets. Eur J Orthod 2012; 34: 232-237.

34. Lai S. C. N., Tay F. R., Cheung G. S., Mak Y. F., Carvalho R. M., Wei S. H., et al. Reversal of compromised bonding in bleached enamel. J Dent Res 2002; 81: 477-481.

35. Zimmerli B., Jeger F., Lussi A. Bleaching of nonvital teeth. A clinically relevant literature review. Schweiz Monatsschr Zahnmed 2010; 120: 306-320.

36. Gokce B., Comlekoglu M. E., Ozpinar B., Türkün M., Kaya A. D. Effect of antioxidant treatment on bond strength of a luting resin to bleached enamel. J Dent Res 2008; 36: 780-785.

37. Hansen J. R., Frick K. J., Walker M. P. Effect of $35 \%$ sodium ascorbate treatment on microtensile bond strength after nonvital bleaching. J Endod 2014; 40:1668-1670.

38. Mirhashemi A., Elham Razavi E. S., Behboodi S., Chiniforush N. Effect of laser-assisted bleaching with $\mathrm{Nd}: Y A G$ and diode lasers on shear bond strength of orthodontic brackets. Lasers Med Sci 2015; 30: 2245-2259.

39. Akın M., Ozyılmaz O. Y., Yavuz T., Aykent F., Basciftci F. A. Effect of Nd: YAG laser bleaching and antioxidizing agents on the shear bond strength of brackets. Photomed Laser Surg 2013; 31: 365-370. 